\title{
COMPARATIVE ANALYSIS OF EVIDENCE BASED- POLICIES IN THE ERA OF DIGITALIZATION
}

\author{
András Bojtor ${ }^{1}$ and Gábor Bozsó ${ }^{2}$
}

DOI: 10.24989/ocg.338.38

\begin{abstract}
A well-functioning administration with embedded institutions enables the formulation of a competitive environment which propitiously effects the country's economic growth. In case of an intervention, the results and impacts should be measured and continuously monitored in a strategic policy cycle. These activities can be done on project and national levels and at the same time there could be a legitimate claim for carrying out international comparative analysis of results. The majority of public administration developments belongs to the scope of e-government. The evidencebased policy making is a component of good governance next to transparency, sustainability, efficiency, integrity and people centricity. Government obligations and responsibilities in evaluations vary from country to country. Digitalization brings new challenges for public service and governments are taking various measures in response to them. Evaluation can fulfil its role in the strategic policy cycle only if it can meet the political conditions with attention to ethical and methodological standards; can adapt to the digitalized circumstances. The paper aims a deeper analysis of evaluation phase, and to summarize the possible new methods reaching better results in public services and public administration services. In this paper we are going to conduct an international comparative analysis with a special attention given to a public administration development program in Hungary.
\end{abstract}

\section{Introduction}

A well-functioning pubic administration can significantly improve the level of well-being through its services. At the same time public administration also affects the competitiveness of countries and businesses. Hungary's Public Administration and Public Service Development Strategy 2014-2020 [1] emphasizes that not only businesses, but also public administration formulates policies that can encourage competitiveness. This paper examines the strategic policy cycle with special attention on the monitoring and evaluating phrases and introduces a framework which allows to conduct comparative analysis of public administration interventions at the evaluation phase. Educational and social interventions are evaluated regularly in the public sector. [2, p. 7] However, except some best practices, [3] there is a shortage of evaluations carried out in case of public administration reforms. By introducing a case study about the Hungarian public administration development program, we demonstrate the difficulties of carrying out evaluations with special focus on international comparisons. The Hungarian Government is committed to improve the competitiveness of public entities, therefore the Public Administration and Civil Service Development Operative Programme (PACSDOP) was introduced with the co-finance of the European Union in the 2013-2020 budgetary cycle.

\footnotetext{
${ }^{1}$ project professional developer, special Office of Research Methodology and Measurement, National University of Public Service

${ }^{2} \mathrm{PhD}$ candidate, special Office of Research Methodology and Measurement, National University of Public Service
} 


\section{Monitoring and evaluation in the strategic policy cycle}

The strategic policy cycle [4, p. 13] demonstrates the steps of handling a referred problem. Interventions are carried out, because a social / economic / environmental problem is revealed and an adequate policy response receives political support and gets implemented. The first step in the strategic policy cycle is the detailed analysis of the problem followed by its prioritizations and objective settings. In case of an EU funded program, the result of the indicator setting can be found in operative programs. Then action planning is followed by costing, monitoring and reporting. Evaluators will hardly dispose sufficient volume of data in the required quality without a wellstructured and well-prepared monitoring system. A functioning monitoring and reporting institution provides the possibility to discover and execute minor corrections in the implementation phase. Reports carried out in the evaluation phase can focus on outputs, outcomes and impacts, but also can evaluate institutional background, operational quality or competence of management. The success of a program, defined consciously beforehand, can also be evaluated. Evaluation findings should already be available in the preparation phase of future programs.

There is not a commonly accepted definition behind some relevant concepts (e.g., outcome, impact [5]) which renders it challenging to execute and interpret evaluations. According to the OECD, the short and midterm results are outcomes, meanwhile impacts are the long-term results. [6, p. 27-28.] To make it more difficult to clarify what is behind these categories, the concept of result-orientation [7, p. 206.] has emerged connected to the 2013-2020 financing period of the European Union. The demand for evaluations parallelly increases with the spread of New Public Management techniques [8]. The European Union is committed to increase citizen satisfaction and intends to improve the efficiency in the use of EU funds [9]. Stakeholder consultation and engagement are expected in every stage of the strategic policy cycle (Figure 1). It can improve transparency, effectiveness and efficacy.

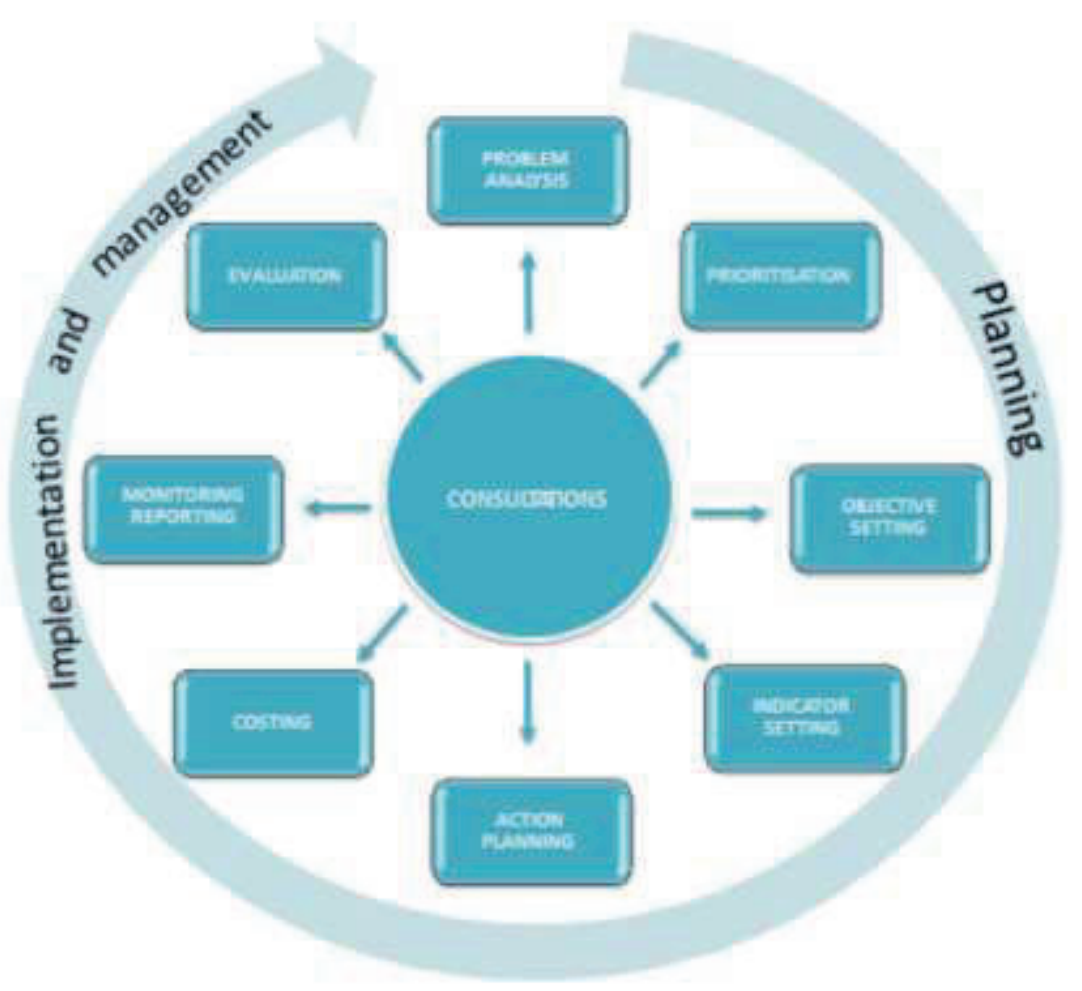

Figure 1: The strategic policy cycle $[4$, p. 13] 
In phase of evaluation, research questions are determined by the evaluation criteria: relevance, coherence, effectiveness, efficiency and EU added value [10] in the case of the European Union. Variety of methods are available: e.g. selecting and analyzing performance indicators, making costbenefit analysis or carrying out multi criteria analysis. The connections between the criteria and the output, result or impact indicators can be observed on Figure 2. It can be seen, that outcomes can refer to results in this model.

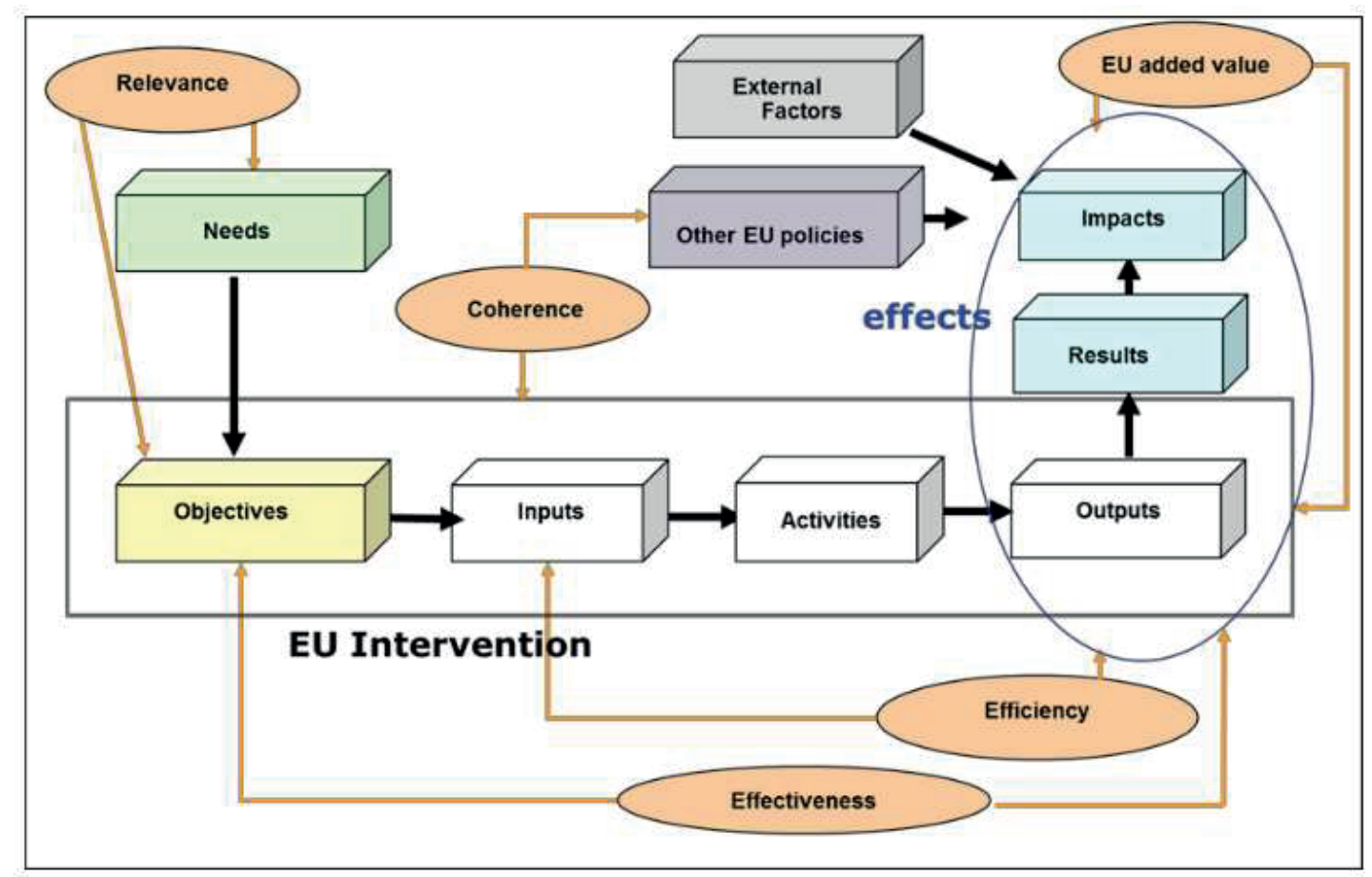

Figure 2: The model of interventions with the evaluation criteria [10, p. 336]

\section{Reforms in the Hungarian public administration}

Hungarian Government introduced several reforms in the past 10 years in the Hungarian public administration that can be defined as "deliberate changes to the structures and processes of public sector organizations with the objective of making them (in some sense) to run better." $[11, p .8]$ The territorial administration was totally restructured, the complete reform of local governments was introduced and the National University of Public Service was established as a main body to provide human resource management of public administration with well-trained and capable human resources, which was also positively evaluated by the OECD [12]. In the background of the centralised reforms, a strong and capable state-theory can be observed [13]. Essential elements of the public administration reform programmes [1], [14], [15] are currently being implemented by developmental projects financed by the Public Administration and Civil Service Development Operative Programme (PACSDOP). More than 935 million euros are planned to be spent on the development of the Hungarian public administration, which plays an important role in the process of improving the performance and efficiency of the Hungarian state with its indirect effects on the competitiveness of the business sector. The outcomes and impacts should be measurable and detectable in international comparisons as well; however, a good evaluation also should be able to distinguish the changes caused directly by the intervention or just a side-effect of unintended circumstances. 


\section{Methodological notes}

International comparative analysis mainly can be carried out based on data collected by international institutions, like International Institute for Management Development, World Economic Forum (WEF), World Bank. Almost always there is an ideology behind these data collections. In some cases include shortage of methodological transparency or defined reasoning of data [16], [17] . In other cases we see that international rankings "simplify social phenomena, level unwarranted normative judgements, and selectively diagnose complex problems"[18, p. 62]. More than 93 different comparative governance indicators exist [19], with various number of countries involved in their data collections. The frequency of their publication (e.g. annually, biannually, or more rarely) is divergent. Between two publications, the methodology behind the same indicator can change radically, which makes it difficult to draw historical conclusions or evaluate their values or rankings. A well-designed, definite ranking is applicable when not only the ranking's objective and dissemination, but also its methodology is taken into consideration [20]. On one hand, a ranking system can cause a huge publicity and can draw the attention to specific issues. It can also encourage quality debates; it can enable the possibility to explore the studying effect. On the other hand, it may also have several disadvantages: the debate can be just about the place in the ranking, it can cause the improvised rediscussion of the long-term strategies [21].

Besides rankings, international indicators can be used in performance evaluations providing comparisons among countries. In case of public administration, the capabilities and capacities of the applied systems show wide varieties. There is a continuous pressure introducing reforms on public administrations. E-government development and digitalization is only a part of public administration reforms. Application of new methodologies like big data analysis (e.g. at the examination of the criminal activity during the Boston Marathon [22] ), experimental research methods in the policymaking processes also augur good results.

Achieving improved competitiveness by digitalization is an important objective of the Hungarian operative program focusing on public administration development. The aggregated results or impacts of the implemented projects can hardly be detected in international rankings exclusively. However, their effectiveness, impacts cannot be denied in level of indicators. In this paper 5 indicators from four worldwide or regional rankings (the Ease of Doing Business, the Digital Economy and Society Index (DESI), the eGovernment Benchmark, the Global Competitiveness Report) are going to be highlighted and briefly discussed to characterize the changes in case of the Hungarian public administration development. The indicator selection was based on (i.) strong validity and reliability to public administration, especially to e-government services and (ii.) its connectivity to economic competitiveness; (iii.) availability of comparative data in EU and benchmark countries. 7

As the PACSDOP is currently in either development or implementation phase, several project results are yet to be delivered likewise its impacts. Furthermore, international rankings and indexes collect previous years' data, in our case 2018, 2019. These two factors only enable us to draw an ex dure, or midterm evaluation only.

\section{International advances of PACSDOP}

Selecting benchmark countries makes it easier to perform comparisons among countries. Analysts have to take into consideration the qualifications and interests of the target audience (who are going to read the evaluations). The projects of the Hungarian public administration development program, 
partially financed from the Cohesion Funds of the European Union, are under implementation. In this case we can talk about intermediate results or impacts. By historical comparisons there is also a need of setting out a base year, when the effects of the program are not perceptible. In our case this year is 2016. Financed projects stepped into implementation phase next year. Data collection requires attention: using the report of Doing Business 2017 means that the data are collected in 2016, Global Competitiveness Report 2017 means that the data are collected in the first part of the same year, in 2017. As the PACSDOP is partially financed by the European Union, there is a need to emphasize the role of the EU, therefore the EU28 average is involved in the performance analysis. The rank of a country means the place among the 28 member states of the European Union.

The eight countries are selected for visualisation (keeping in mind relevance): Estonia (as a country which generally performs well in digitalization as a consequence of early introduced well designed digital reforms), the V4 countries (Slovakia, Czech Republic, Poland and Hungary) plus Slovenia (as EU countries with similar history and culture) and finally Bulgaria and Romania (as countries joined the EU together following the 2004 enlargement).

Developing e-government services is of little worth, if citizens and businesses are not committed to use them. Its EU wide applied indicator is the e-government users, collected by the Eurostat. It measures people who sent filled forms to public authorities, over the internet, in the previous 12 months aged between 16-74 years. Figure 3 shows that number of Hungarian users significantly increased from the base year, however lagging behind the two third of EU countries and EU28 average. Several new services were introduced (e.g. Hungarian Tax Authority introduced an electronic system of income tax return (eSZJA)) in line with legislative changes to promote egovernmental services. Later on, higher increase is expected as more development projects enters implementation phase.

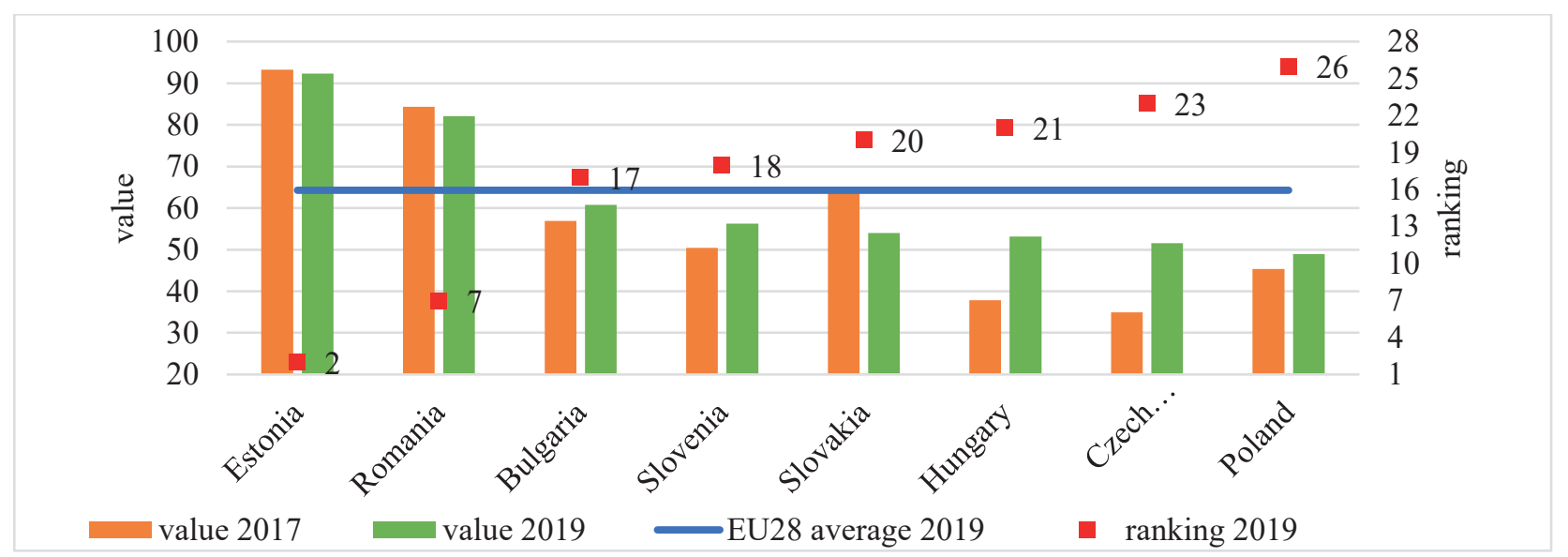

Figure 3: E-government users in different countries and their rankings in EU28 Source: https://digital-agenda-data.eu/

Users can choose to use e-governmental service only if it is available and they can easily adopt them. It is measured by the highly comprehensive user centricity indicator collected within the eGovernment Benchmark. The user centricity improved in all the visualized countries meaning that governments are committed to improve availability of services and paying attention to user satisfaction. It also can be assumed that their feedbacks are more important and taken into consideration by the developers. Figure 4 shows that all countries have made progress, but not good enough to outperform the last third, except Estonia. Hungary has gained relative position overcoming 4 countries in the past two years. [23] 


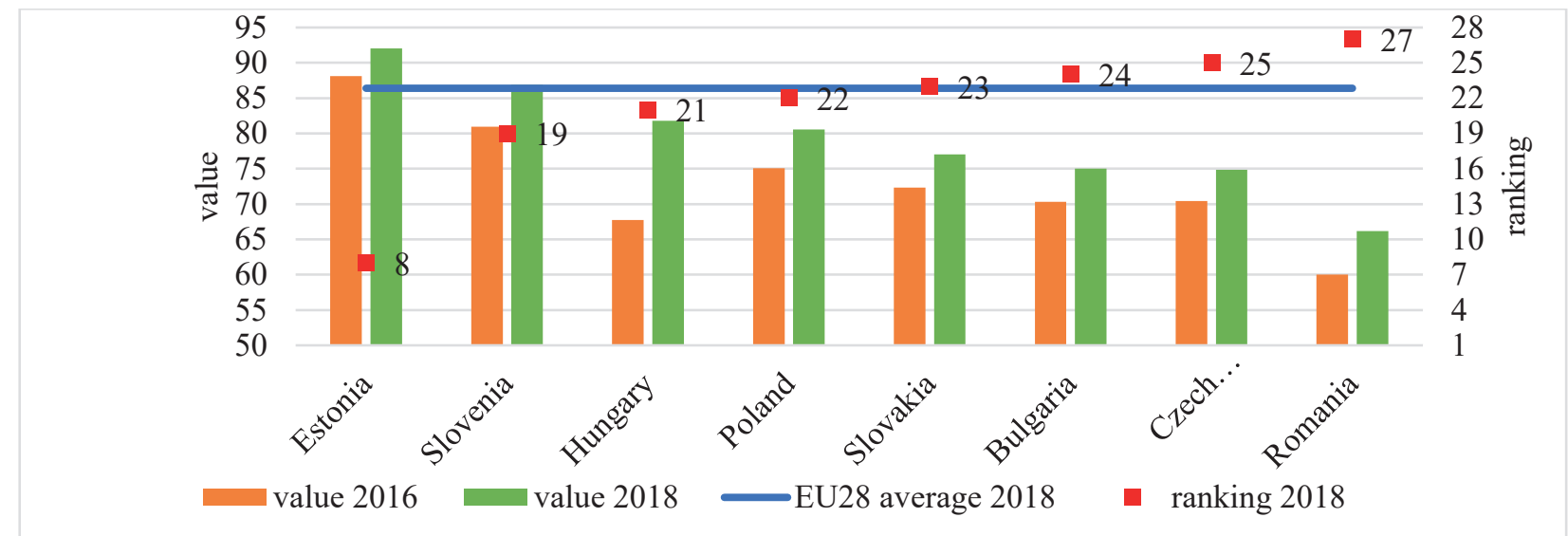

Figure 4: The user centricity values in the base year (2016) and in the latest available data (2018) Source: https://ec.europa.eu/digital-single-market/en/news/egovernment-benchmark-2019-trust-governmentincreasingly-important-people

As e-governmental services are developed to provide easier and more cost-effective way of using public services, it is necessary to save users time. This can be reached if the identified user's data are filled automatically if it has already been given previously by the user. This is measured by a mystery shopping technique in various life events e.g. applying for unemployment aid. This indicator can increase on one hand by the development of the infrastructure and the interoperability between various data centers, and on the other hand by the satisfaction of citizens, meaning the improvement of user-experience. In case of Hungary, we can find adequate and significant improvement.

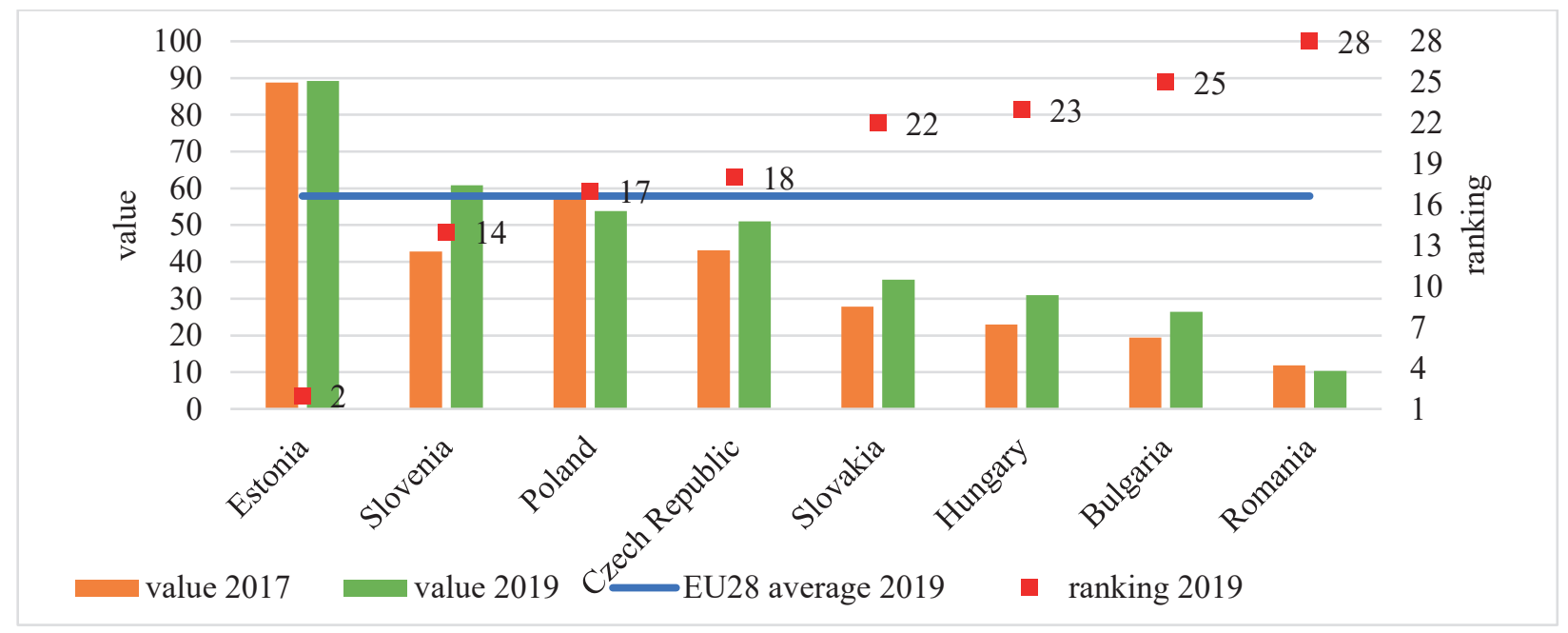

Figure 5: Prefilled forms

Source : https://digital-agenda-data.eu/

Not only e-government development can be compared internationally, but also some relevant selected sectors. As an illustration, we have chosen the taxation indicator of the Doing Business ranking system. The Hungarian tax system is usually criticised because of its rates and complexity. Several reforms were introduced recently, the rate of taxation was decreased, the tax-system was simplified and the level of digitalization, like automated income tax return (partially financed by the EU funds), was improved. All the activities together improved the taxation indicator. 


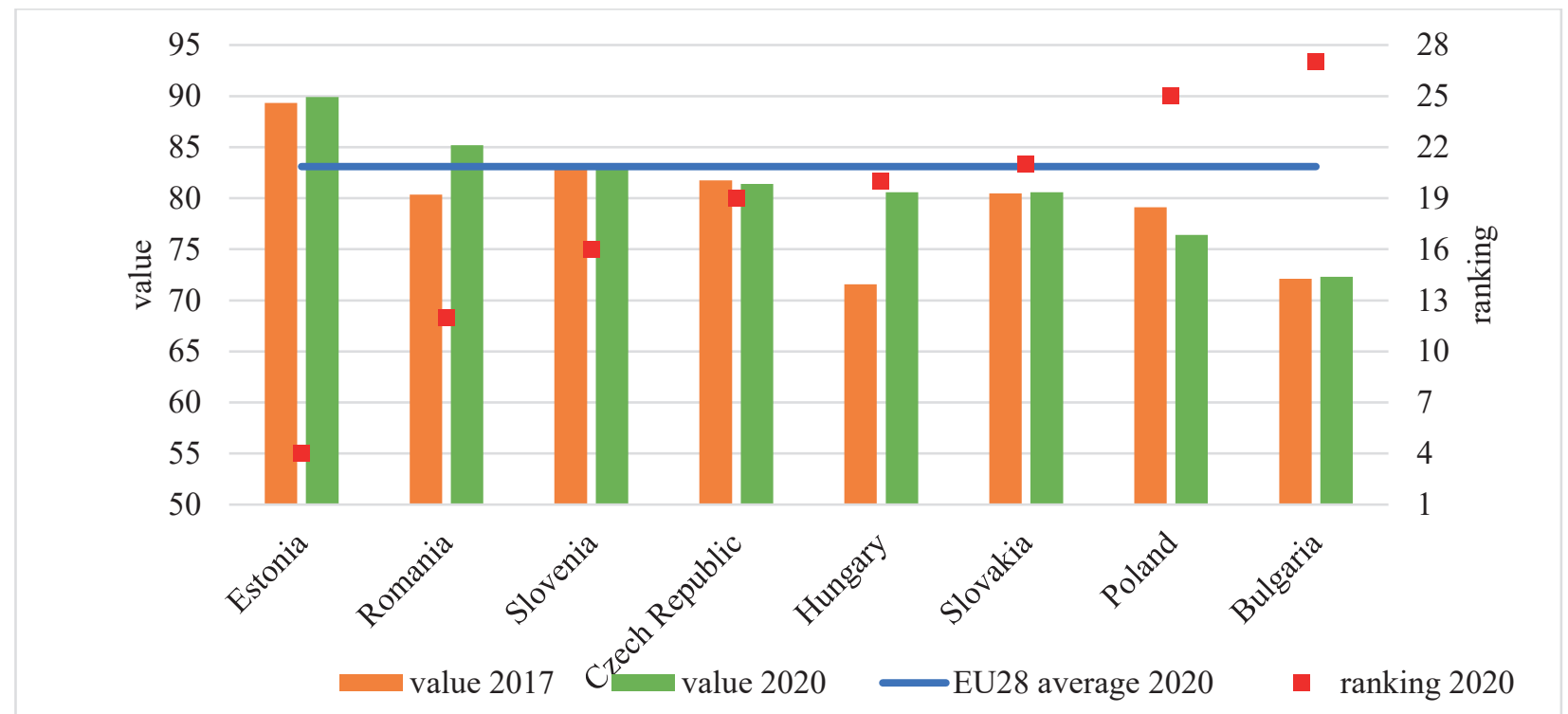

Figure 6: The values in 2017 (as base year) and in 2020 (as midterm year) and the ranking of taxation in 2020

Source: www.doingbusiness.com

International surveys also provide useful data for making comparisons. The WEF annually performs the Executive Opinion Survey that provides soft data about competitiveness. Among others it asks "In your country, how burdensome is it for companies to comply with public administration's requirements (e.g. permits, regulations, reporting)?" which can be replied with a 7 scaled scale where $1=$ extremely burdensome and $7=$ not burdensome. The more than 16000 answers can improve the credibility of results. [23]

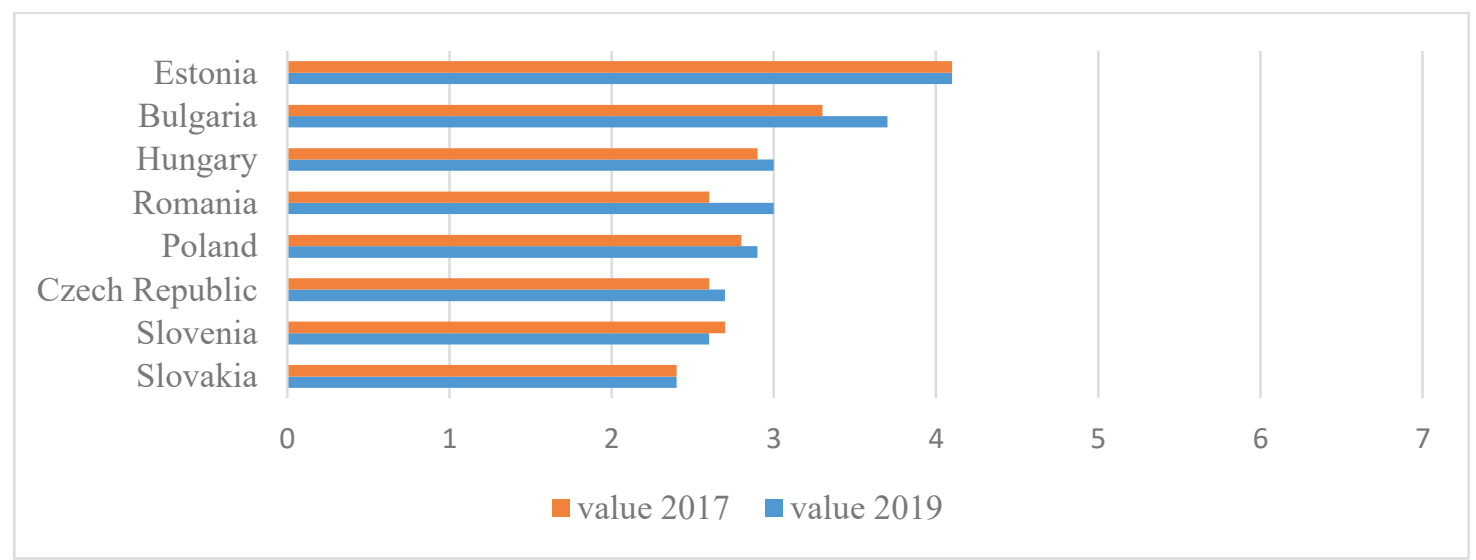

Figure 7: The burden of government regulation [23]

\section{Conclusions}

We have demonstrated the role of evaluation in the strategic policy cycle of public administration. As we have seen, evaluations are rarely carried out in this field, and international comparisons also have their limits. It is less evident to find the proper indicators for featuring the impacts of an implemented public policy program.

The selected international indicators evaluating the performance of the Hungarian public administration development program are various; some of them are based on hard data (e.g. government users) while others on soft data (administrative burden). These constraints should be 
taken into consideration by evaluators. The example of taxation presented that the changes of an indicator can be caused by several factors, like changes in legislation, or technological development etc. The process of making evaluation is a balance of costs and benefits, which means that the more precise evaluation required, the more resource needed (more costly), and the value of the intervention should also be in line with that cost.

Most countries show visible improvements in the selected indicators and Hungary (alongside with Bulgaria) outperformed all countries by improving or significantly improving its values since 2016 . Four out of the five indicators gained substantially (by $10 \%$ or more) and the one remaining also improved slightly. Speaking of relative position in rankings, it is worth noting that these advancements were only enough to close the gap and gain some places, but Hungarian values still yet to reach EU average in all 5 indicators examined.

The final conclusion is that the performance of the Hungarian public administration has improved and most probably is going to improve in the future compared to 2016. There are several projects in the implementation phase waiting its results and outcomes to evolve. An indicator showing an increase does not necessary mean that the country gains place in the rankings. It shows only the direction and an increase relative to others, while that other countries can improve their performance more rapidly and effectively.

It also important to keep in mind that not all the impacts of a project can be measured and other impacts can bring numbers down. Normative way of thinking can limit the borders of discovery, significant factors can lurk in the background.

\section{References}

[1] Miniszterelnökség, Közigazgatás- és Közszolgáltatás-fejlesztési Stratégia 2014-2020. 2015.

[2] DAHLER-LARSEN, P., The evaluation society. Stanford University Press, 2011.

[3] Republika e Kosovës Republika Kosova-Republic of Kosovo Qeveria-Vlada-Government, Public Administration Reform Strategy (2010-2013), 2010.

[4] OECD, Toolkit for the preparation, implementation, monitoring, reporting and evaluation of public administration reform and sector strategies: guidance for SIGMA partners, 2018.

[5] BELCHER B. and PALENBERG, M., "Outcomes and Impacts of Development Interventions: Toward Conceptual Clarity," American Journal of Evaluation, vol. 39, no. 4, pp. 478-495, May 2018.

[6] OECD, "Glossary of key terms in evaluation and results-based management.," Paris, 2002.

[7] MCCANN, P., The regional and urban policy of the European Union: Cohesion, resultsorientation and smart specialisation. Edward Elgar Publishing, 2015.

[8] WOLlMANN, H., Policy Evaluation and Evaluation Research, in F. Fischer, J. G. Miller, and S. M. Sidney, (eds.), Handbook of Public Policy Analysis and Methods CRS Press, 2007.

[9] PATTYN, V. et al., "Policy Evaluation in Europe," 2018, pp. 577-593. 
[10] European Commission, "Better Regulation Toolbox [SWD (2015) 111]." European Commission Brussels, 2015.

[11] SAVOIE, D. J., POLliTT, C. and BOUCKAERT, G., (2011) Public Management Reform: A Comparative Analysis - New Public Management, Governance, and the Neo-Weberian State, International Review of Administrative Sciences, vol. 78, no. 1, pp. 180-182, Mar. 2012.

[12] OECD, Hungary: Public Administration and Public Service Development Strategy, 2014-2020, 2017.

[13] BALÁZS, I., A közigazgatás változásairól Magyarországon és Európában a rendszerváltástól napjainkig, Debrecen: Debreceni Egyetemi Kiadó, 2016.

[14] Közigazgatási és Igazságügyi Minisztérium, Magyary Zoltán közigazgatás-fejlesztési program (MP 12.0), 2012.

[15] Közigazgatási és Igazságügyi Minisztérium, Magyary Zoltán közigazgatás-fejlesztési program (MP 11.0), 2011.

[16] NÉMETH, E., VARGA, B. T. and PÁLYI, K. Á., Nemzetközi korrupciós rangsorok tudományos megbízhatósága, Pénzügyi Szemle, pp. 321-337, 2019.

[17] VARGHA, B. T., NÉMETH, E. and PÁLYI K. Á., Mit mutatnak a versenyképességi rangsorok?, Pénzügyi Szemle, no. 3, pp. 352-370, 2019.

[18] Cooley, A., How International Rankings Constitute and Limit Our Understanding of Global Governance Challenges: The Case of Corruption, in The Palgrave Handbook of Indicators in Global Governance, Cham: Springer International Publishing, 2018, pp. 49-67.

[19] ROTBERG, R. I., On Governance: What It Is, What It Means and Its Policy Uses. McGillQueen's Press-MQUP, 2016.

[20] GIFFINGER, R., HAINDLMAIER, G. and KRAMAR H., "The role of rankings in growing city competition," Urban Research and Practice, vol. 3, no. 3, pp. 299-312, 2010.

[21] SCHÖNERT, M., “Städteranking und Imagebildung,” 2003.

[22] PIROG, M. A., Data will drive innovation in public policy and management research in the next decade, Journal of Policy Analysis and Management, vol. 33, no. 2, pp. 537-543, Mar. 2014.

[23] KLAUS, S., The Global Competitiveness Report 2019, 2019. 